\title{
Experimental study on accumulation of heavy metals in vegetables irrigated with treated wastewater
}

\author{
Athar Hussain $^{1} \cdot$ Manjeeta Priyadarshi $^{2} \cdot$ Shashikant Dubey ${ }^{3}$
}

Received: 21 June 2017 / Accepted: 3 June 2019 / Published online: 10 June 2019

(c) The Author(s) 2019

\begin{abstract}
Treated sewage and industrial effluents are used for irrigation of crops in developing countries which may contain heavy metals in high concentration. It can contaminate soil and accumulate in vegetables. In the present study, the vegetables were irrigated with treated wastewater brought from a nearby full-scale sewage treatment plant. The concentration levels of the $\mathrm{Cd}, \mathrm{Co}, \mathrm{Cu}, \mathrm{Mn}$ and $\mathrm{Zn}$ in the leaves were found below toxic limits as prescribed in the literature. Daily intake metals values suggest that the consumption of plants grown in treated wastewater and tap water is nearly free of risks, as the dietary daily intake limits of $\mathrm{Cu}, \mathrm{Fe}, \mathrm{Zn}$, and $\mathrm{Mn}$ in adults can range from 1.2 to $3 \mathrm{mg}, 10$ to $50 \mathrm{mg}, 5$ to $22 \mathrm{mg}$ and 2 to $20 \mathrm{mg}$, respectively. The enrichment factor for the treated wastewater irrigated soil was found to decrease in order of $\mathrm{Zn}>\mathrm{Ni}>\mathrm{Pb}>\mathrm{Cr}>$ $\mathrm{Cu}>\mathrm{Co}>\mathrm{Mn}>\mathrm{Cd}$.
\end{abstract}

Keywords Heavy metals $\cdot$ Daily metal intake $\cdot$ Enrichment factor $\cdot$ Wastewater

\section{Introduction}

Due to rapid increase in population in urban area, high volume of waste water is generated every day. In many developing countries including India, farmers have initiated irrigation of their crops with industrial effluents due to non-availability of any other source. However, effluent from municipal sewage treatment plants often contains high levels of macro- and micro-nutrients along with heavy metals.

Contamination of soil with heavy metals in agricultural fields cultivated by industrial effluents has emerged as a new threat. The percolation of these pollutants through the soil causes degradation of soil. Soil pollution is caused mainly by spreading of pollutants on surface of soil. Surface pollutants come from many sources like waste (solid or liquid)

Athar Hussain

athariitr@gmail.com; athar.hussain@gov.in

1 Civil Engineering Department, Ch. Brahm Prakash Government Engineering College, Jaffarpur, New Delhi 110073, India

2 Civil Engineering Department, Environmental Engineering Section, School of Engineering, Gautam Buddha University, Greater Noida, UP 201312, India

3 Department of Civil and Environmental Engineering, Hindustan College of Science and Technology, Farah, India disposal practices, spills, modern agricultural practices and percolation of surface pollutants through unsaturated soil (Patil et al. 2014).

Large areas of agricultural land are contaminated by heavy metals that mainly originate from mining activities, industrial discharges or the application of sewage sludge. Metals may exist in one of four forms in the soil: mineral, organic, sorbed (bound to soil) or dissolved. Sorbed metals represent the third largest pool and are generally very tightly bound to soil surface. Although mineral, organic and sorbed metals are not immediately absorbed by plants, they can slowly release metals into solution (Jones and Jacobsen 2009). The essential elements like $\mathrm{Cr}, \mathrm{Cu}, \mathrm{Co}, \mathrm{Fe}, \mathrm{Mn}, \mathrm{Mo}$, $\mathrm{Ni}$, Se and $\mathrm{Zn}$ are required by organisms in trace amount and become toxic at higher levels. Non-essential elements including $\mathrm{As}, \mathrm{Sb}, \mathrm{Cd}, \mathrm{Pb}, \mathrm{Hg}, \mathrm{Sn}$ and $\mathrm{Ag}$ are toxic and not required by organism (Mc Grath 2001). Most of the industrial effluents and wastes contain heavy metals in an amount sufficient enough to cause toxicity to crop plants (Naz et al. 2015).

The trace elements including $\mathrm{Cu}, \mathrm{Zn}, \mathrm{Mn}, \mathrm{Fe}$ and $\mathrm{B}$ are essential micro-nutrients required for plant growth. These elements are also considered as heavy metals as they may be toxic to plants at high concentrations (Parveen et al. 2015). Wastewater treatment plant (WWTP) is a main concern for environmentalists, as it gives rise to environmental impacts 
due to its energy consumption, use of chemicals, emissions to the atmosphere and sludge production. Disposal of high amount of sludge generated from wastewater treatment plants is a big problem.

Agricultural land can be contaminated with heavy metals if it is irrigated with wastewater coming directly from urban areas or other polluted sources, constant application of fertilizers and agro-chemicals containing heavy metals. It has been shown that crops and vegetables cultivated in soil which is irrigated with water containing heavy metals may accumulate a greater quantity of heavy metals (Alrawiq et al. 2014). The ecological balance gets affected due to widespread contamination of soil. Most plants are unable to grow when chemistry of the soil changes in short period of time. In these conditions, fungi and bacteria found in the soil also begin to decline, creating an additional problem of soil erosion. Soils are able to accumulate heavy metals for many years without showing signs of their acute toxic effect. The purification capacity of soils is finite, as above a certain level, soils are no longer able to absorb these elements and become source of pollution themselves. Toxic elements are released from many sources into water and absorbed by cultivated crops and plants. Thereafter they are assimilated into vegetative, generative organs and also enter food chain. Sahito et al. (2016) assessed bioaccumulation of heavy metals in vegetables grown in soil amended with poultry waste as a fertilizer. A study conducted by Jamali et al. (2007) indicated increased danger of growing vegetables in soil irrigated and dressed with wastewater and sewage sludge. A typical range of metals in soil derived from normal and geochemically anomalous parent material in Britain is shown in Table 1.

Vegetables are considered to be an important component of human diet as they are rich sources of vitamins, minerals and fibers. However, the intake of the vegetables contaminated with heavy metals may pose a risk to human health (Parveen et al. 2015). Vegetables provide the human body with essential trace elements which are necessary for healthy life. Heavy metal pollution represents an important environmental problem due to its toxic effects and accumulation throughout the food chain.

Heavy metals may be absorbed and accumulate in edible and non-edible parts of vegetables in such a concentration that can cause adverse health effects in animals. Some metals present in vegetables are important biochemically and psychologically from health point of view. Heavy metals may also adversely affect growth of plants as they can influence biochemical processes such as photosynthesis and stomata opening.

Absorption and accumulation of metals in plant depend on many factors, such as $\mathrm{pH}, \mathrm{EC}$, clay content, organic matter content and physical and mechanical characteristics of soil. Plants take heavy metals from soil through different reactions, such as absorption, ionic exchange, redox reactions (El Zabalawy et al. 2015).

The study has been carried out by irrigating carrot, spinach and radish with different concentrations of treated sewage effluent in order to observe the effects on growth of plants and accumulation of heavy metals.

\section{Materials and methods}

In the present study, the vegetables were grown in premises of school of architecture, Gauatm Buddha University, Greater Noida, U.P., India. The soil was brought from village named Dankaur near the campus. Also, sample of treated sewage was brought for irrigation from 137 MLD sewage treatment plant located at village named Kasna near the campus. The vegetables selected for the study are carrot (Daucus

Table 1 Metals in soils derived from normal and geochemically anomalous parent material in Britain (Nriagu 1984)

\begin{tabular}{|c|c|c|c|c|}
\hline Metals & $\begin{array}{l}\text { Typical range } \\
(\mathrm{mg} / \mathrm{kg})\end{array}$ & $\begin{array}{l}\text { Metals rich soil } \\
(\mathrm{mg} / \mathrm{kg})\end{array}$ & Sources & Possible effects \\
\hline \multirow[t]{2}{*}{ As } & $<5-40$ & Up to 2500 & Mineralization & Toxicity in plant and live stocks \\
\hline & & Up to 250 & Metamorphosed rocks around Dart moor & Accumulation in food crops \\
\hline \multirow[t]{2}{*}{$\mathrm{Cd}$} & $<1-2$ & Up to 30 & Mineralization & Accumulation in food crops \\
\hline & & Up to 20 & Carboniferous black shale & - \\
\hline $\mathrm{Cu}$ & $2-60$ & Up to 2000 & Mineralization & Toxicity in cereal crops \\
\hline Mo & $<1-5$ & $10-100$ & Marine black shales of varying age & $\begin{array}{l}\text { Molybdenosis or molybdenum induced } \\
\text { hypocuprosis in cattle }\end{array}$ \\
\hline $\mathrm{Ni}$ & $2-100$ & Up to 8000 & Ultra basic rocks in Scotland & Toxicity in cereal and other crops \\
\hline $\mathrm{Pb}$ & $10-150$ & $1 \%$ or more & Mineralization & Toxicity in live stocks, excess in food stuffs \\
\hline $\mathrm{Se}$ & $<1-2$ & $\begin{array}{l}\text { Up to } 7 \\
\text { Up to } 500\end{array}$ & $\begin{array}{l}\text { Marine black shales in England and Wales } \\
\text { Namurian shales in Ireland }\end{array}$ & Chronic selenosis in horses and cattle \\
\hline $\mathrm{Zn}$ & $25-200$ & $1 \%$ or more & Mineralization & Toxicity in cereal crops \\
\hline
\end{tabular}




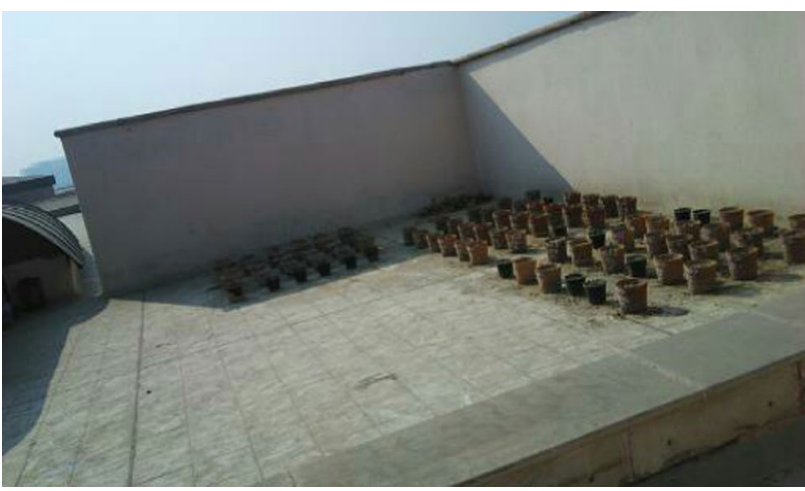

Fig. 1 Image of 90 pots for growing vegetables used in the present study

Carota Subsp Sativus), radish (Raphanus Sativus) and spinach (Spinacea Oleracea). These vegetables were grown on pretreated soil filled in properly labeled pots as shown in Fig. 1.

\section{Analysis of water, treated wastewater and soil}

Samples of soil were collected from an agricultural area in village Dankaur. During preliminary study, physicochemical characteristics ( $\mathrm{pH}$, electric conductivity, Total $\mathrm{N}, \mathrm{P}, \mathrm{K}, \mathrm{Na}$, $\mathrm{Mg}$ and $\mathrm{Ca}$ ) along with heavy metals $(\mathrm{Cd}, \mathrm{Ni}, \mathrm{Mn}, \mathrm{Cr}, \mathrm{Pb}$, $\mathrm{Co}, \mathrm{Zn}, \mathrm{Cu}$ ) in samples of soil, water and treated wastewater were determined as per the standard methods (American Public Health Association 2000). All the samples were pretreated by digestion with $1 \mathrm{~mL}$ nitric acid and $3 \mathrm{~mL}$ perchloric acid before analysis for heavy metals. Samples were filtered using whattman filter paper (No. 45). The filtrate obtained was used for analysis of heavy metals using atomic absorption spectrophotometer (Model GBC Avanta M). The heavy metals analyzed in the present study are $\mathrm{Cd}, \mathrm{Ni}, \mathrm{Mn}$, $\mathrm{Cr}, \mathrm{Pb}, \mathrm{Cu}, \mathrm{Zn}$ and $\mathrm{Co}$.

\section{Preparation of pots}

The vegetables were grown in the pots by using a statistical approach (simple randomized block design method) suggested by Parveen et al. (2015). Study was carried out during January-April 2016. Ninety pots (with weight $1.8 \mathrm{~kg}$ each) of $20 \mathrm{~cm}$ diameter were filled with $5 \mathrm{~kg}$ of soil. Plants were harvested after 60 days time, being enough to construe the maturity which is known as days after sowing (DAS) period. Water and treated wastewater were used for irrigation of vegetables. The composition of water (control) and treated wastewater used for watering these pots was varied during the study. Vegetables were irrigated under five different conditions (1) 100\% tap water, (2) 75\% tap water with $25 \%$ treated wastewater, (3) 50\% tap water with 50\% treated wastewater, (4) $25 \%$ tap water with $75 \%$ treated wastewater and (5) $100 \%$ treated wastewater. Each set containing 6 pots and duplicates of plant samples were carefully uprooted at 60 DAS with minimum damage to the root and leaf.

\section{Pretreatment of samples}

Plant samples were driven out carefully from the pots and washed with tap water to remove soil particles. The plants were conserved in polypacks prior to analysis as shown in Fig. 2. The measurement of growth of plant and its parts as leaf (length and width), root (thickness, length) and stem was done using vernier calipers. Afterward roots and leaves were separated and dried in oven below $80{ }^{\circ} \mathrm{C}$. The dried samples were digested with $1 \mathrm{~mL}$ nitric acid $\left(\mathrm{HNO}_{3}\right)$ and $3 \mathrm{~mL}$ perchloric acid $\left(\mathrm{HClO}_{4}\right)$ as per the procedure given in the HACH Manual.

\section{Daily intake of metals (DIM)}

Daily intake of metal (DIM) was determined by using following equation $(\mathrm{Eq} 1)$ :

$\mathrm{DIM}=C_{\text {metal }} \times C_{\text {factor }} \times D_{\text {food intake }} / B_{\text {average weight }}$

where $C_{\text {metal }}, C_{\text {factor }}, D_{\text {food intake }}, B_{\text {average weight }}$ represent the heavy metal concentrations in plants $(\mathrm{mg} / \mathrm{g})$, conversion factor, daily intake of vegetables and average body weight of humans, respectively. A conversion factor of 0.085 was used to convert weight of fresh vegetable to dry weight. The average daily vegetable intake for adults and children was taken as 0.345 and $0.232 \mathrm{~kg} /$ person/day, respectively, while the average body weight of adult and children was taken as 55.9 and $32.7 \mathrm{~kg}$, respectively (Khan et al. 2008).

\section{Enrichment factor (Ef)}

The term enrichment factor is defined as degree of contamination of soil in terms of accumulation of heavy metal in

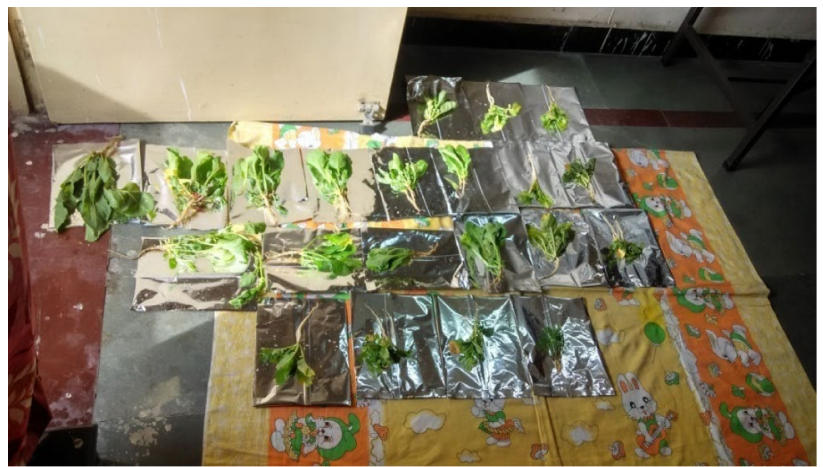

Fig. 2 Samples of grown vegetables collected for analysis after washing with tap water 
soil and plants growing on such a contaminated site with respect to soil and plants grown on uncontaminated site. The enrichment factor (Ef) for metals accumulated in soil and vegetables by irrigation using treated wastewater was calculated by following equation (Eq. 2)

Enrichment factor $(\mathrm{Ef})=\frac{\text { mean content of metal in the sample }}{\text { mean content of metal in the control }}$

The data obtained were analyzed statistically. The measurement is expressed in terms of mean values and standard errors for duplicates. Value of $0.5 \leq \mathrm{EF} \leq 1.5$ suggests that the trace metal concentration may occur because of natural weathering processes (Zhang and Liu 2002). The enrichment factor close to unity $(\mathrm{EF}=1)$ indicates that the element under consideration originated from the soil (Chiarenzelli et al. 2001), whereas enrichment factor of value more than 1.5 indicates that a significant portion of the trace metals was delivered from non-crustal material (Sutherland et al. 2000).

\section{Results and discussion}

The results obtained from analysis of samples of soil, water and treated wastewater in terms of physicochemical parameters are summarized in Table 2. The heavy metals analyzed are $\mathrm{Pb}, \mathrm{Zn}, \mathrm{Cr}, \mathrm{Cu}, \mathrm{Ni}, \mathrm{Mn}, \mathrm{Co}$ and $\mathrm{Cd}$. The concentration of the heavy metals present in treated wastewater and soil was within the permissible limits. Also, the concentration of all heavy metals is found to be higher in treated wastewater than in the soil. Soil texture was loamy sand having great influence on growth of root and its ability to absorb water which ensures optimum growth for root vegetables.

Organic matter is an important source of plant nutrients. It also increases water holding capacity, ion exchange capacity and soil fertility as it regulates water and air supply in soil, which in turn controls rate at which nutrients are absorbed by roots. The average $\mathrm{pH}$ value of soil was observed to be 8.97 , and the uptake of nutrients by various vegetables is dependent on $\mathrm{pH}$. Result from the study indicates high $\mathrm{pH}$ values of soil as compared to the $\mathrm{pH}$ of treated wastewater (effluent) (Table 3).

\section{Measurement of plant growth}

The growth of different vegetables has been measured with respect to the total weight of plant, length of root, width of leaf and length of shoots in terms of plant height, leaf number and root diameter. The data for the same are summarized in Table 4. The growth of vegetables was affected by the concentration of treated wastewater used for irrigation. The growth was found to be maximum in plants irrigating with $100 \%$ treated wastewater as compared to the plants irrigated with $0,25,50$ and $75 \%$ of treated wastewater.

The weight of the plants roots and leaves was found to be increasing with respect to time in a 60 days period. The presence of nitrogen and phosphorus along with potassium also enhances the growth of vegetables. In the present study, as sufficient concentration of potassium was present in the treated wastewater as well as in the soil, the growth of vegetable plants has been found to be enormous. In case of lower potassium concentration, the growth rate, cell size and water content of the tissues may be reduced. Another macro-nutrient, $\mathrm{Ca}$ which is found treated wastewater has an important role in the structure and permeability of cell membranes and division, thereby promoting growth.

The micro-nutrients, such as $\mathrm{Cl}$, play most important role in opening and closing of stomata which is vital for gaseous exchange and increasing photosynthesis. It is also required for cell division in leaves and shoots. Another important micro-nutrient is iron which normally ranges between 50 and $250 \mathrm{mg} / \mathrm{L}$ in plants. Also, $\mathrm{Cu}$ acts as an electron carrier and a part of plastocyanin which has an important role in photosynthesis and accumulation of dry matter. The involvement of Mn in photosynthesis, particularly in the evolution of oxygen, is well known. Zinc concentration should range between 25 and $150 \mathrm{mg} / \mathrm{L}$ in plants, and its deficiency
Table 2 Physicochemical parameters of treated wastewater and soil

\begin{tabular}{llllllllllll}
\hline Parameter & $\mathrm{pH}$ & $\mathrm{EC}(\mu \mathrm{mho} / \mathrm{cm})$ & $\mathrm{N}$ & $\mathrm{P}$ & $\mathrm{K}$ & $\mathrm{Na}$ & $\mathrm{Ca}$ & $\mathrm{Mg}$ & $\mathrm{TOC}(\%)$ & $\mathrm{NO}_{3}-\mathrm{N}$ & $\mathrm{TSS}$ \\
\hline Soil $^{\mathrm{a}}$ & 8.97 & 420 & 5.5 & 0 & 11 & 27 & 12 & 468 & 3.6 & 3.24 & - \\
Treated wastewater $^{\mathrm{a}}$ & 8.28 & 582 & 20 & 4.7 & 15 & 305 & 20 & 356 & - & 0.78 & 240 \\
\hline
\end{tabular}

${ }^{\mathrm{a}}$ Units: soil (mg/g); treated wastewater $(\mathrm{mg} / \mathrm{L})$ except $\mathrm{pH}$, conductivity and TOC values

\begin{tabular}{lllllllll}
\hline Parameters & $\mathrm{Cd}$ & $\mathrm{Ni}$ & $\mathrm{Cu}$ & $\mathrm{Zn}$ & $\mathrm{Mn}$ & $\mathrm{Pb}$ & $\mathrm{Cr}$ & $\mathrm{Co}$ \\
\hline Soil (mg/g) & 0.0310 & 0.207 & 0.150 & 0.084 & 0.026 & 0.196 & 0.266 & 0.069 \\
$\begin{array}{l}\text { Treated wastewa- } \\
\text { ter (mg/L) }\end{array}$ & 0.033 & 0.257 & 0.171 & 0.077 & 0.012 & 0.150 & 0.227 & 0.071 \\
\hline
\end{tabular}

Table 3 Concentration of heavy metals in treated wastewater and soil (before irrigation)
يو لردينة الملك عبدالعزيز

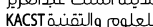


Table 4 Growth parameters of the vegetables

\begin{tabular}{|c|c|c|c|c|c|c|c|c|c|}
\hline \multicolumn{2}{|c|}{ Concentration (\%) } & \multirow[t]{2}{*}{ No. of crops } & \multirow[t]{2}{*}{ No of leafs } & \multirow{2}{*}{$\begin{array}{l}\text { Weight of } \\
\text { plant (gm) }\end{array}$} & \multirow[t]{2}{*}{ Size of leave $(\mathrm{cm})$} & \multirow{2}{*}{$\begin{array}{l}\text { Width of } \\
\text { leave }(\mathrm{cm})\end{array}$} & \multirow{2}{*}{$\begin{array}{l}\text { Width of } \\
\operatorname{root}(\mathrm{mm})\end{array}$} & \multirow{2}{*}{$\begin{array}{l}\text { Length of } \\
\text { root }(\mathrm{cm})\end{array}$} & \multirow{2}{*}{$\begin{array}{l}\text { Total height } \\
\text { of plant }(\mathrm{cm})\end{array}$} \\
\hline Tap water & $\begin{array}{l}\text { Treated } \\
\text { waste } \\
\text { water }\end{array}$ & & & & & & & & \\
\hline \multicolumn{10}{|l|}{ Spinach } \\
\hline \multirow[t]{2}{*}{100} & 0 & 1. & 12 & 5.9 & $8-13.5$ & 4.2 & 1 & 9.3 & 23 \\
\hline & & 2. & 11 & 5.5 & $7-12$ & 4.2 & 1 & 8.5 & 20.8 \\
\hline \multirow[t]{2}{*}{75} & 25 & 3. & 16 & 11.86 & $8-15$ & 5 & 1.5 & 17 & 27.3 \\
\hline & & 4. & 12 & 8.4 & $7-14$ & 4.3 & 2 & 14 & 29.8 \\
\hline \multirow[t]{2}{*}{50} & 50 & 5. & 24 & 44.6 & $16-26$ & 9 & 3 & 14 & 40 \\
\hline & & 6. & 23 & 11.39 & $9-15$ & 5.8 & 1.5 & 13 & 50 \\
\hline \multirow[t]{2}{*}{25} & 75 & 7. & 23 & 35.5 & $9-17.8$ & 5.5 & 2.5 & 11 & 28.5 \\
\hline & & 8. & 17 & 6.48 & $6-11.5$ & 4.5 & 1.5 & 8 & 19 \\
\hline \multirow[t]{2}{*}{0} & 100 & 9. & 18 & 25.4 & $9-17$ & 5.5 & 3 & 21 & 43 \\
\hline & & 10. & 35 & 16.5 & $9-18$ & 6 & 3.1 & 11 & 29.7 \\
\hline \multicolumn{10}{|l|}{ Radish } \\
\hline \multirow[t]{2}{*}{100} & 0 & 1. & 8 & 5.3 & $5-9$ & 3.3 & 2 & 9 & 18 \\
\hline & & 2. & 11 & 4.38 & $6-9.8$ & 4 & 1 & 10.6 & 19 \\
\hline \multirow[t]{2}{*}{75} & 25 & 3. & 12 & 14 & $10-13.3$ & 5 & 1.6 & 10 & 24 \\
\hline & & 4. & 6 & 5.87 & $6-8$ & 4 & 2.1 & 12 & 20 \\
\hline \multirow[t]{2}{*}{50} & 50 & 5. & 7 & 3.5 & $6-9$ & 3.5 & 0.5 & 7 & 16 \\
\hline & & 6. & 7 & 3.22 & $5-7.5$ & 3.9 & 1 & 10 & 16.3 \\
\hline \multirow[t]{2}{*}{25} & 75 & 7. & 8 & 3.62 & $5-8.5$ & 3 & 1.1 & 11 & 19 \\
\hline & & 8. & 9 & 3.33 & $5-7$ & 3 & 0.7 & 8 & 15 \\
\hline \multirow[t]{2}{*}{0} & 100 & 9. & 12 & 11 & $8-11$ & 5 & 2 & 11 & 22 \\
\hline & & 10. & 13 & 7.4 & $5.5-9$ & 3.4 & 0.9 & 10.5 & 19 \\
\hline \multicolumn{10}{|c|}{ Carrot physical measurement } \\
\hline 100 & 0 & 1. & 6 & 3.1 & - & - & 0.7 & 4 & 10 \\
\hline 75 & 25 & 2. & 8 & 3.62 & - & - & 0.92 & 3.8 & 11.8 \\
\hline 50 & 50 & 3. & 10 & 5.2 & - & - & 1 & 5 & 12.7 \\
\hline 25 & 75 & 4. & 7 & 4.1 & - & - & 0.98 & 3.7 & 9.4 \\
\hline 0 & 100 & 5. & 9 & 3.3 & - & - & 0.88 & 5 & 10.9 \\
\hline
\end{tabular}

adversely affects the development of leaf as leaf margins are often distorted (Marschner 2002).

\section{Heavy metal accumulation and translocation ratio in plants}

In the present study, the heavy metals were determined in leaves and roots of radish, spinach and carrot grown in a 60-day period. Concentration of all heavy metals in different parts of different vegetable plants is tabulated in Table 5. The concentration of $\mathrm{Cd}$ varied from 20.5 to $39.5 \mathrm{mg} / \mathrm{g}$, while concentration of $\mathrm{Ni}$ was found between 100 and $545 \mathrm{mg} / \mathrm{g}$. The concentration of $\mathrm{Cu}$ was observed in the range of 22 to $324 \mathrm{mg} / \mathrm{g}$, while the concentration of $\mathrm{Zn}$ was found between
152 and $259 \mathrm{mg} / \mathrm{g}$. The concentration of Mn was observed in the range of 106.5 to $429 \mathrm{mg} / \mathrm{g}$, while the concentration of $\mathrm{Pb}$ was found between 72.5 and $346 \mathrm{mg} / \mathrm{g}$. The concentration of $\mathrm{Cr}$ was observed between 84 and $441 \mathrm{mg} / \mathrm{g}$, and the concentration of Co was found between 12 and $77 \mathrm{mg} / \mathrm{g}$.

Results from the study indicate that concentration of heavy metals $\mathrm{Cd}, \mathrm{Co}$ and $\mathrm{Pb}$ in the root samples was found to be below the toxic limit. Concentration of heavy metals in leaves was found to decrease in order of $\mathrm{Zn}>\mathrm{Ni}>\mathrm{Cr}>\mathrm{P}$ $\mathrm{b}>\mathrm{Mn}>\mathrm{Cu}>\mathrm{Co}>\mathrm{Cd}$, while in the roots it was in the order of $\mathrm{Zn}>\mathrm{Ni}>\mathrm{Cr}>\mathrm{Pb}>\mathrm{Mn}>\mathrm{Cu}>\mathrm{Co}>\mathrm{Cd}$. Concentration of $\mathrm{Zn}$ was found to be higher in plant samples irrigated with tap water. Also, the concentration of $\mathrm{Zn}$ was observed to be high in the roots than in the leaves, and it decreased with 
Table 5 Concentration of heavy metals in various parts of vegetable plants

\begin{tabular}{|c|c|c|c|c|c|c|c|c|c|c|}
\hline \multicolumn{3}{|c|}{ Concentration $(\%)$} & \multicolumn{8}{|c|}{ Concentration of heavy metals in radish $(\mathrm{mg} / \mathrm{g})$} \\
\hline Tap water & $\begin{array}{l}\text { Treated waste } \\
\text { water }\end{array}$ & Part of plant & $\mathrm{Cd}$ & $\mathrm{Ni}$ & $\mathrm{Cu}$ & $\mathrm{Zn}$ & $\mathrm{Mn}$ & $\mathrm{Pb}$ & $\mathrm{Cr}$ & $\mathrm{Co}$ \\
\hline \multirow[t]{2}{*}{100} & 0 & Root & 0.033 & 0.062 & 0.05 & 0.302 & 0.106 & 0.092 & 0.1 & 0.002 \\
\hline & & Leaf & 0.039 & 0.138 & 0.07 & 0.256 & 0.148 & 0.12 & 0.068 & 0.046 \\
\hline \multirow[t]{2}{*}{75} & 25 & Root & 0.034 & 0.071 & 0.075 & 0.214 & 0.103 & 0.025 & 0.058 & 0.03 \\
\hline & & Leaf & 0.04 & 0.152 & 0.07 & 0.2 & 0.131 & 0.177 & 0.181 & 0.015 \\
\hline \multirow[t]{2}{*}{50} & 50 & Root & 0.037 & 0.094 & 0.108 & 0.226 & 0.063 & 0.098 & 0.221 & 0.023 \\
\hline & & Leaf & 0.039 & 0.184 & 0.05 & 0.225 & 0.15 & 0.161 & 0.207 & 0.001 \\
\hline \multirow[t]{2}{*}{25} & 75 & Root & 0.033 & 0.1 & 0.023 & 0.07 & 0.102 & 0.005 & 0.212 & 0.001 \\
\hline & & Leaf & 0.04 & 0.133 & 0.021 & 0.322 & 0.147 & 0.14 & 0.157 & 0.039 \\
\hline \multirow[t]{2}{*}{0} & 100 & Root & 0.038 & 0.093 & 0.054 & 0.3 & 0.1 & 0.117 & 0.065 & 0.039 \\
\hline & & Leaf & 0.041 & 0.125 & 0.101 & 0.243 & 0.173 & 0.15 & 0.134 & 0.035 \\
\hline \multicolumn{3}{|c|}{ Concentration (\%) } & \multicolumn{8}{|c|}{ Concentration of heavy metals in spinach $(\mathrm{mg} / \mathrm{g})$} \\
\hline Tap water & $\begin{array}{l}\text { Treated waste } \\
\text { water }\end{array}$ & Part of plant & $\mathrm{Cd}$ & $\mathrm{Ni}$ & $\mathrm{Cu}$ & $\mathrm{Zn}$ & Mn & $\mathrm{Pb}$ & $\mathrm{Cr}$ & Co \\
\hline \multirow[t]{2}{*}{100} & 0 & Root & 0.042 & 0.18 & 0.01 & 0.237 & 0.15 & 0.176 & 0.223 & 0.028 \\
\hline & & Leaf & 0.02 & 0.197 & 0.129 & 0.318 & 0.195 & 0.234 & 0.275 & 0.087 \\
\hline \multirow[t]{2}{*}{75} & 25 & Root & 0.04 & 0.148 & 0.049 & 0.256 & 0.145 & 0.164 & 0.147 & 0.042 \\
\hline & & Leaf & 0.023 & 0.235 & 0.09 & 0.327 & 0.235 & 0.269 & 0.261 & 0.096 \\
\hline \multirow[t]{2}{*}{50} & 50 & Root & 0.043 & 0.17 & 0.076 & 0.246 & 0.145 & 0.264 & 0.338 & 0.029 \\
\hline & & Leaf & 0.02 & 0.204 & 0.071 & 0.213 & 0.299 & 0.174 & 0.092 & 0.045 \\
\hline \multirow[t]{2}{*}{25} & 75 & Root & 0.036 & 0.204 & 0.088 & 0.221 & 0.146 & 0.184 & 0.198 & 0.043 \\
\hline & & Leaf & 0.022 & 0.215 & 0.095 & 0.326 & 0.261 & 0.181 & 0.197 & 0.071 \\
\hline \multirow[t]{2}{*}{0} & 100 & Root & 0.017 & 0.213 & 0.112 & 0.213 & 0.14 & 0.21 & 0.36 & 0.001 \\
\hline & & Leaf & 0.024 & 0.218 & 0.058 & 0.227 & 0.126 & 0.112 & 0.209 & 0.005 \\
\hline \multicolumn{3}{|c|}{ Concentration (\%) } & \multicolumn{8}{|c|}{ Concentration of heavy metals in carrot $(\mathrm{mg} / \mathrm{g})$} \\
\hline Tap water & $\begin{array}{l}\text { Treated waste } \\
\text { water }\end{array}$ & Part of plant & $\mathrm{Cd}$ & $\mathrm{Ni}$ & $\mathrm{Cu}$ & $\mathrm{Zn}$ & $\mathrm{Mn}$ & $\mathrm{Pb}$ & $\mathrm{Cr}$ & Co \\
\hline \multirow[t]{2}{*}{100} & 0 & Root & 0.021 & 0.225 & 0.066 & 0.152 & 0.273 & 0.104 & 0.283 & 0.077 \\
\hline & & Leaf & 0.019 & 0.235 & 0.067 & 0.234 & 0.235 & 0.112 & 0.208 & 0.086 \\
\hline \multirow[t]{2}{*}{75} & 25 & Root & 0.023 & 0.23 & 0.162 & 0.197 & 0.429 & 0.128 & 0.282 & 0.083 \\
\hline & & Leaf & 0.034 & 0.232 & 0.177 & 0.212 & 0.411 & 0.137 & 0.105 & 0.055 \\
\hline \multirow[t]{2}{*}{50} & 50 & Root & 0.024 & 0.228 & 0.085 & 0.215 & 0.198 & 0.234 & 0.235 & 0.083 \\
\hline & & Leaf & 0.027 & 0.219 & 0.105 & 0.238 & 0.217 & 0.256 & 0.229 & 0.088 \\
\hline \multirow[t]{2}{*}{25} & 75 & Root & 0.027 & 0.545 & 0.145 & 0.265 & 0.145 & 0.202 & 0.357 & 0.064 \\
\hline & & Leaf & 0.034 & 0.435 & 0.211 & 0.355 & 0.245 & 0.241 & 0.249 & 0.088 \\
\hline \multirow[t]{2}{*}{0} & 100 & Root & 0.026 & 0.465 & 0.324 & 0.259 & 0.163 & 0.346 & 0.441 & 0.052 \\
\hline & & Leaf & 0.031 & 0.343 & 0.298 & 0.287 & 0.137 & 0.424 & 0.398 & 0.055 \\
\hline
\end{tabular}

respect to time as the plant attained growth. The variation in concentration of metals in these vegetables depends on physicochemical nature of the soil and absorption capacity for each metal by the plant. It is affected by the various factors like environmental condition, human interference and the nature of the plant.

Among the eight heavy metals, $\mathrm{Cd}$ and $\mathrm{Co}$ were found to be in lower concentration as compared to other heavy metals. 
This may be due to their high dependability on solubility and $\mathrm{pH}$ of soil. The results from the present study indicated that concentration of heavy metal is higher in leaves and roots of the plants that are irrigated with $25 \%, 50 \%, 75 \%$ of treated wastewater as compared to the plants irrigated with $100 \%$ treated wastewater. It was not astounding because the metals uptake may be different in relation to external concentration and genotype of plant.

It may also be pointed out that uptake of heavy metals in plants is not linear in relation to treated wastewater concentration. The concentration of $\mathrm{Zn}$ was found to be maximum in spinach irrigated with $25 \%$ treated wastewater and radish irrigated with $75 \%$ treated wastewater after 60 days time.
Fig. 3 Variation in concentration of heavy metals in various parts of radish a $\mathrm{Ni} \mathbf{b} \mathrm{Cu} \mathbf{c} \mathrm{Cr} \mathbf{d}$ $\mathrm{Co}$ e $\mathrm{Zn} \mathbf{f} \mathrm{Mn} \mathbf{g} \mathrm{Pb} \mathbf{h} \mathrm{Cd}$

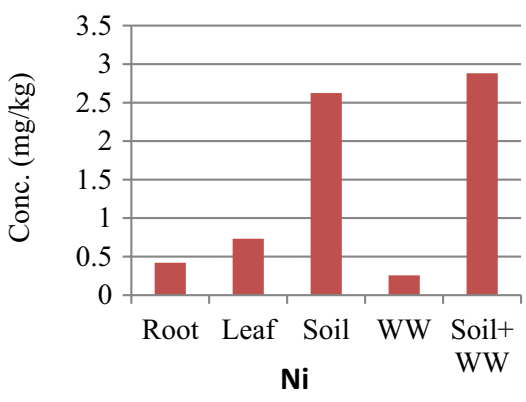

(a)

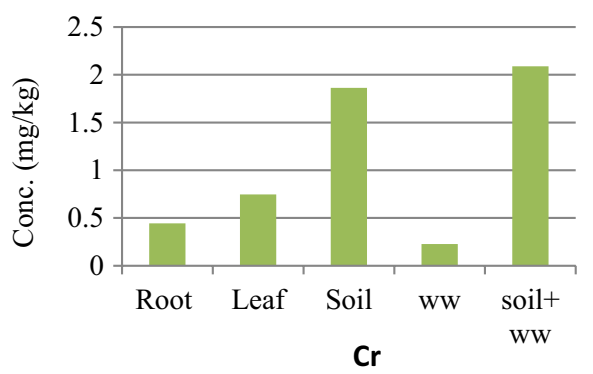

(c)

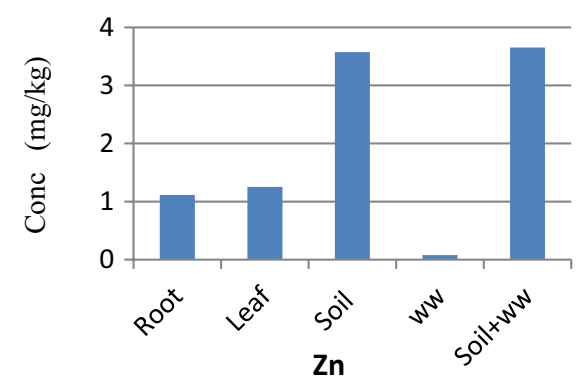

(e)

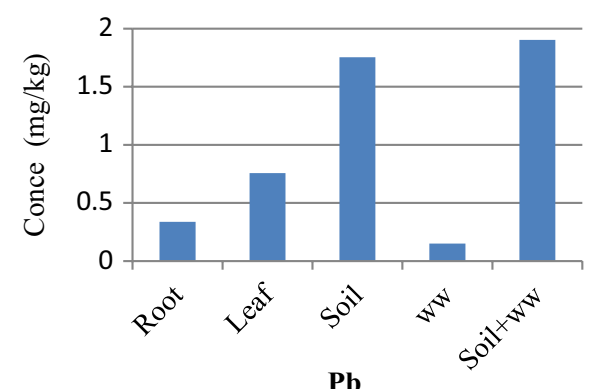

(g)

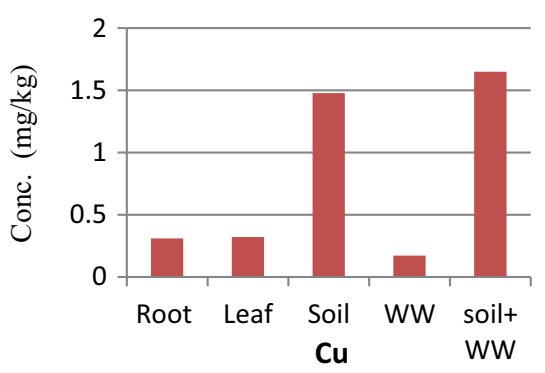

(b)

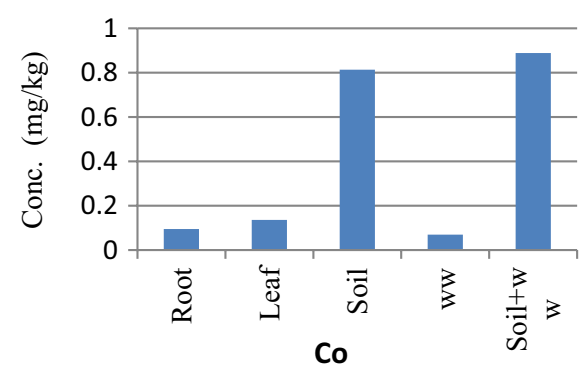

(d)

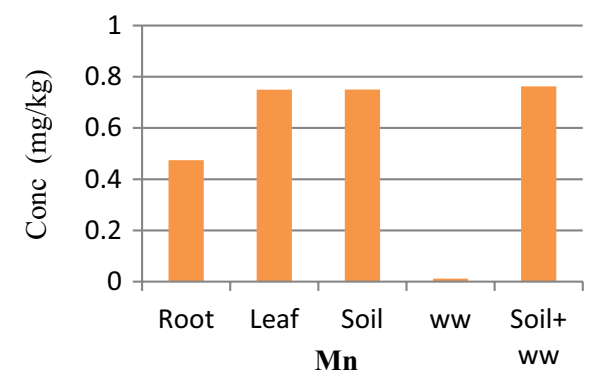

(f)

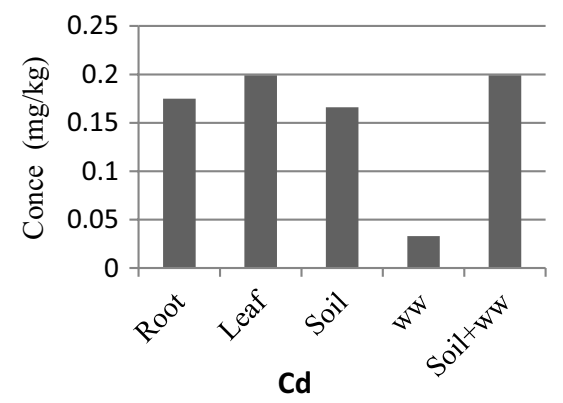

(h) 
The result also indicates that concentration of $\mathrm{Zn}$ is maximum in leaves than in roots. The concentration was found to normally decrease in roots with increased growth of plant. The concentration of $\mathrm{Cd}$ was found to be higher in roots of spinach then in leaves which is also in agreement with the work carried out by Demirezen and Aksoy (2004).

In the present study, the concentration of $\mathrm{Cd}$ was found between 20.5 and $39.5 \mathrm{mg} / \mathrm{g}$. Figure 3 indicates that concentration of $\mathrm{Cd}, \mathrm{Co}$, and $\mathrm{Cu}$ is low and below the toxic levels in leaves and roots of all the vegetables. The concentration of $\mathrm{Cu}$ was found between 22 and $324 \mathrm{mg} / \mathrm{g}$ in all the plants. The concentration of $\mathrm{Cr}$ and Co ranged between 84 to $441 \mathrm{mg} / \mathrm{g}$ and 12 to $77 \mathrm{mg} / \mathrm{g}$, respectively. Concentration of $\mathrm{Cr}$ was higher in the leaves of the spinach and carrot. However, in radish the concentration was high in roots as compared to the leaves.
Fig. 4 Variation of heavy metals concentration in various parts of spinach vegetable a $\mathrm{Ni}$ b $\mathrm{Cu} \mathbf{c}$ $\mathrm{Cr} \mathbf{d} \mathrm{Co}$ e $\mathrm{Zn} \mathbf{f} \mathrm{Mn} \mathbf{g} \mathrm{Pb} \mathbf{h} \mathrm{Cd}$

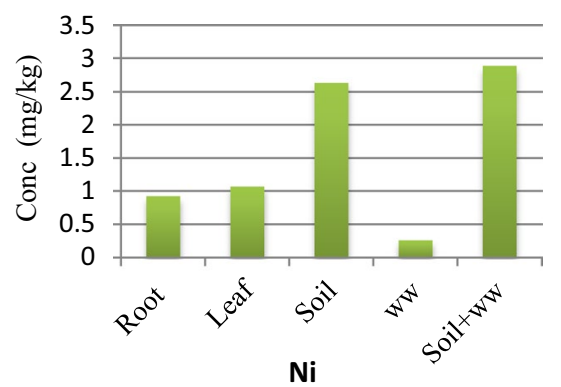

(a)

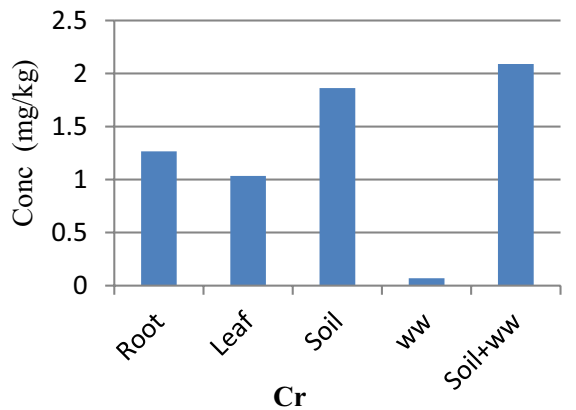

(c)

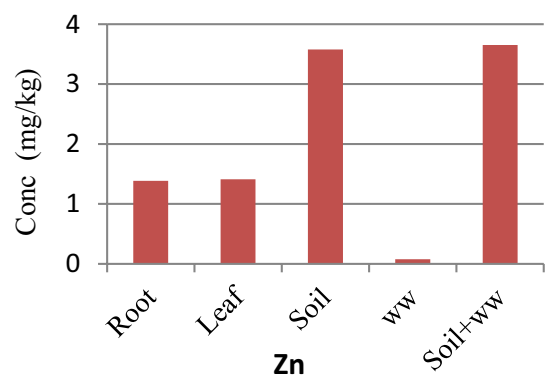

(e)

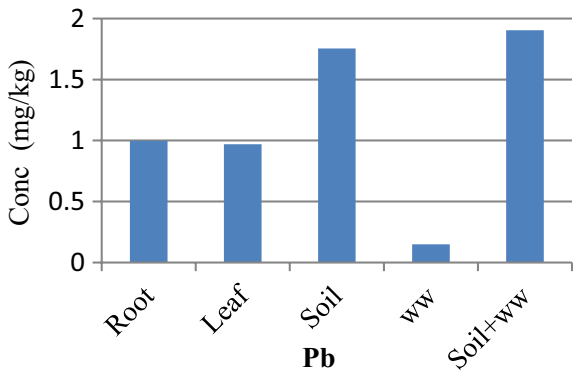

(g)

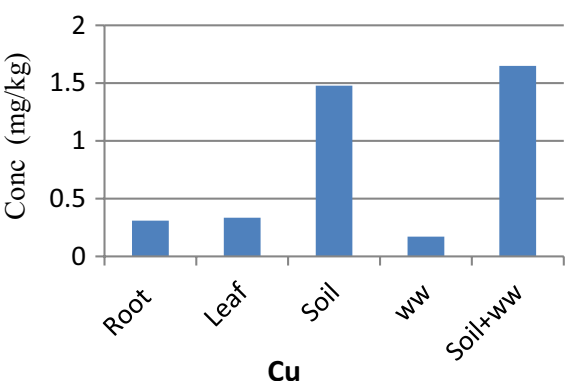

(b)

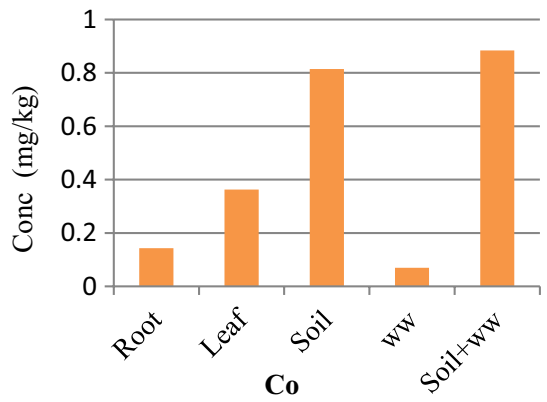

(d)

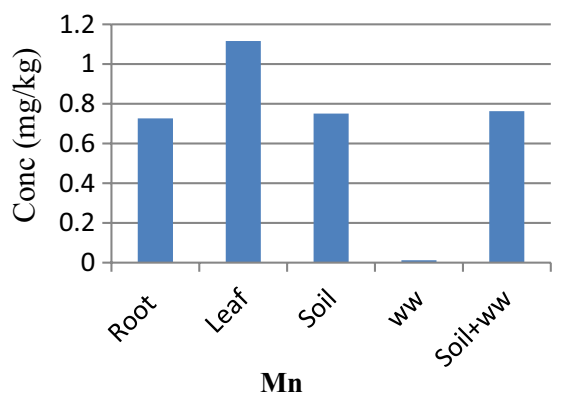

(f)

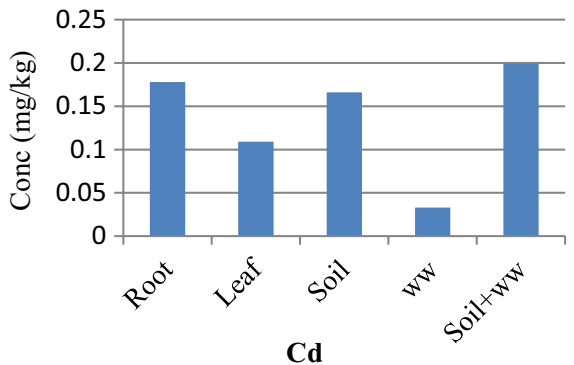

(h) 
Fig. 5 Soil enrichment factor of heavy metals irrigated with treated wastewater

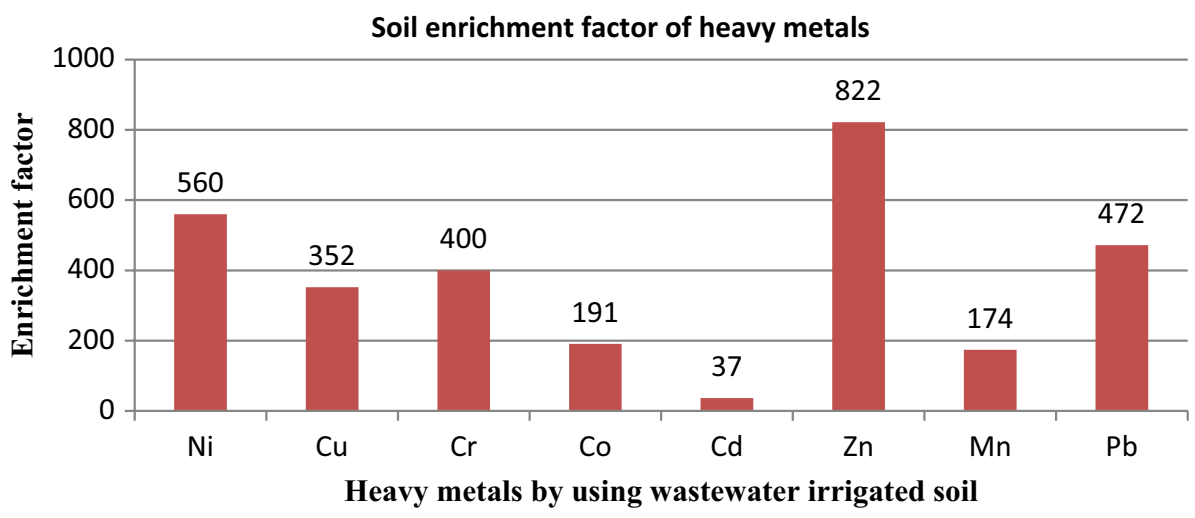

The concentration of $\mathrm{Ni}$ was higher in the leaves of all the vegetables plants ranging between 100 and $545 \mathrm{mg} / \mathrm{g}$. The concentration of $\mathrm{Mn}$ in all vegetable plants was found to be in the range of 106.5 to $429 \mathrm{mg} / \mathrm{g}$ which is lower than toxic level. The concentration of $\mathrm{Zn}$ and $\mathrm{Pb}$ ranged from 152 to $259 \mathrm{mg} / \mathrm{kg}$ and 72.5 to $346 \mathrm{mg} / \mathrm{kg}$, respectively. The translocation factor was analyzed from data, and it was found that heavy metals accumulate more in the shoots of the plants than in roots (Fig. 4).

The concentration of the heavy metals in the soil irrigated with mixture of treated waste water and normal ground water was in the order of $\mathrm{Fe}>\mathrm{Mn}>\mathrm{Cr}>\mathrm{Zn}>\mathrm{P}$ $\mathrm{b}>\mathrm{Cu}>\mathrm{Cd}$ and $\mathrm{Fe}>\mathrm{Zn}>\mathrm{Cr}>\mathrm{Mn}>\mathrm{Pb}>\mathrm{Cu}>\mathrm{Cd}$. The results indicated that the average concentration of heavy metals, except for $\mathrm{Cd}$, was higher in the soil irrigated with treated water than in the soil irrigated with normal ground water. The concentration of heavy metals was higher in the soil except for $\mathrm{Cd}, \mathrm{Cu}$ and $\mathrm{Mn}$, which may be attributed to their weak adsorption in the soil.

\section{Enrichment factor for soil}

The enrichment factor for the soil irrigated with treated wastewater was found to decrease in the order of $\mathrm{Zn}>\mathrm{Ni}$ $>\mathrm{Pb}>\mathrm{Cr}>\mathrm{Cu}>\mathrm{Co}>\mathrm{Mn}>\mathrm{Cd}$. The value for the same is shown in Fig. 5. The enrichment factor has been found to be maximum for $\mathrm{Zn}$ and is found to be minimum for $\mathrm{Cd}$.

\section{Daily intake of metals (DIM)}

The daily intake of heavy metals was evaluated based on average consumption of vegetables for both adults and children. The daily intake of metals for adults and children through the consumption of plants irrigated with treated wastewater is summarized in Table 6. The daily intakes of metals were higher during consumption of plants gown in treated wastewater than those grown in control. Perusal of the data summarized in Table 6 regarding DIM suggests that consumption of plants grown in treated wastewater and tap water is nearly free of risks, as the dietary daily intake limits of micro-nutrients such as $\mathrm{Cu}, \mathrm{Fe}, \mathrm{Zn}$, and $\mathrm{Mn}$ in adults can range from 1.2 to $3 \mathrm{mg}, 10$ to $50 \mathrm{mg}, 5$ to $22 \mathrm{mg}$ and 2 to $20 \mathrm{mg}$, respectively (WHO 1996). The highest DIM values in both adults and children were measured in $\mathrm{Zn}$ followed by $\mathrm{Cr}$, $\mathrm{Ni} \mathrm{Pb}, \mathrm{Mn}, \mathrm{Co}, \mathrm{Cu}$ and $\mathrm{Cd}$.

\section{Conclusion}

The yield obtained was high in plants irrigated with treated wastewater because of the presence of more nutrients as compared to that of tap water. The concentration of heavy metals in vegetable plants irrigated with treated wastewater was at excessive levels at 60 DAS. The concentration of heavy metals in plants was found to be decreasing in the order of $\mathrm{Zn}>\mathrm{Ni}>\mathrm{Cr}>\mathrm{Pb}>\mathrm{Mn}>\mathrm{Cu}>\mathrm{Co}>\mathrm{Cd}$. The concentration of heavy metals is found to be higher in the edible parts of plant (leaves and roots). Consumption of plants grown in treated wastewater has shown high value of DIM as compared to those grown in tap water, but is nearly free from risks. The daily intake of metals $(\mathrm{Zn}, \mathrm{Ni}, \mathrm{Mn}, \mathrm{Cu}, \mathrm{Pb}$, $\mathrm{Cr}, \mathrm{Co}, \mathrm{Cd}$ ) for human with body weight (adults $=55.9 \mathrm{~kg}$ and children $=32.7 \mathrm{~kg}$ ) indicates that intake of toxic metals from vegetables is not high. It can be inferred that excesses level of heavy metals accumulates in the plant root. The root of such plants may be considered as toxic for human or animal consumption and should be discarded from the plants if possible. 


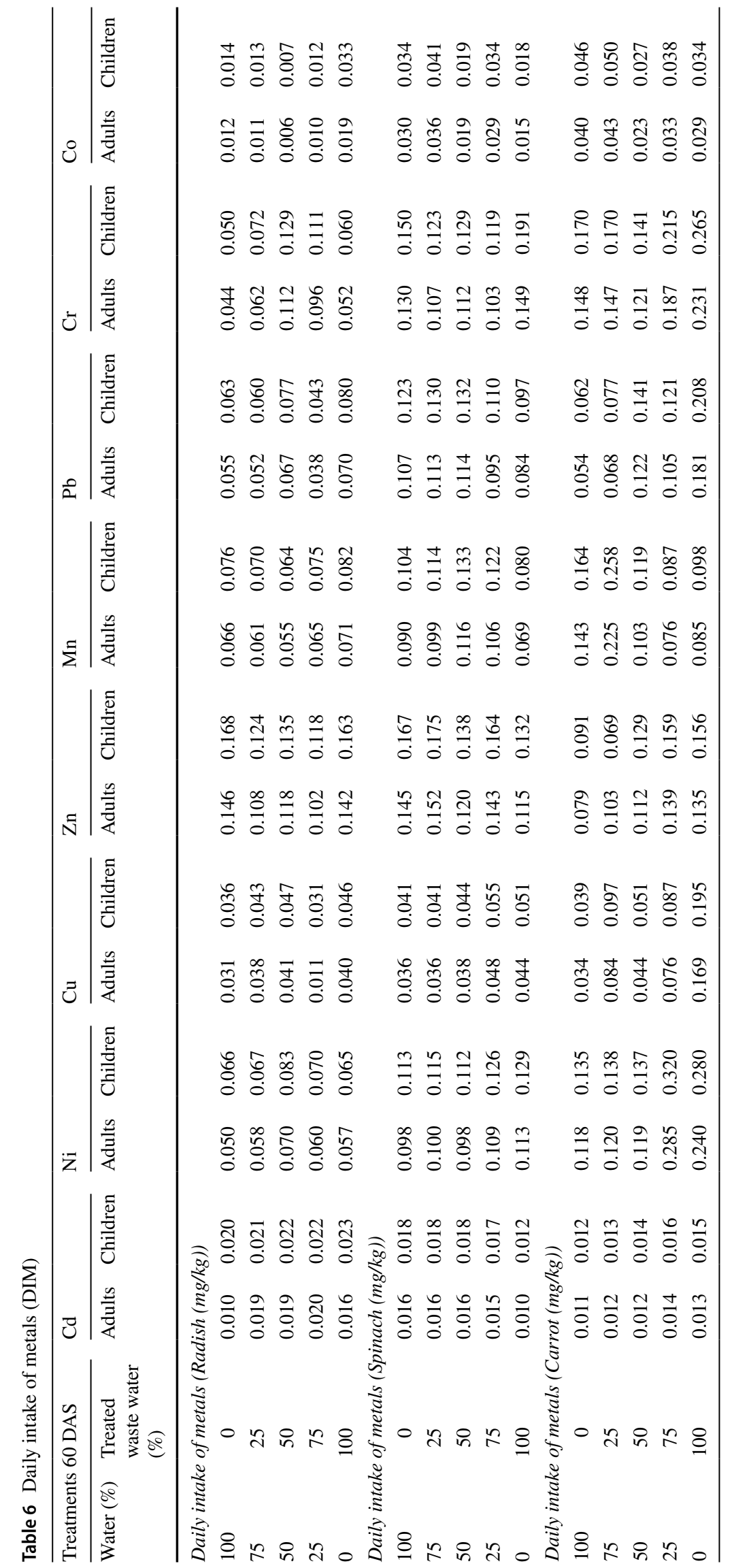


Open Access This article is distributed under the terms of the Creative Commons Attribution 4.0 International License (http://creativeco mmons.org/licenses/by/4.0/), which permits unrestricted use, distribution, and reproduction in any medium, provided you give appropriate credit to the original author(s) and the source, provide a link to the Creative Commons license, and indicate if changes were made.

\section{References}

Alrawiq N, Khairiah J, Talib ML, Ismail BS, Anizan I (2014) Accumulation and translocation of heavy metals in soil and paddy plant samples collected from rice fields irrigated with recycled and non recycled water in MADA Kedah, Malaysia. Int J Chem Tech Res 6(4):2347-2356

Chiarenzelli JR, Aspler LB, Dunn C, Cousens B, Ozarko DL, Powis KB (2001) Multi element and rare earth element composition of lichens, mosses and vascular plants from the central barren lands, Nunavut, Canada. Appl Geochem 16:245-270

Demirezen D, Aksoy A (2004) Accumulation of heavy metals in Typha Angustifolia (L.) and Potamogeton Pectinatus (L.) living in Sultan Marsh (Kayseri, Turkey). Chemosphere 56:685-696

El Zabalawy MKh, Abou-Shleel MS, Abdel-Kareem SM (2015) Effect of marine on bio-accumulation of heavy metals from polluted soil by some leafy vegetables. Nat Sci 13(3):109-116

Jamali MK, Kazi TG, Arain MB, Afridi HI, Jalbani N, Memon AR (2007) Heavy metal contents of vegetables grown in soil, irrigated with mixtures of wastewater and sewage sludge in Pakistan, using ultrasonic-assisted pseudo-digestion. J Agron Crop Sci 193:218-228

Jones C, Jacobsen J (2009) Micronutrients: cycling, testing and fertilizer recommendations. Nutrient management module 7. Montana State University Extension Service. Publication 4449-7, Issue 7, pp 1-16

Khan S, Cao Q, Zheng MY, Huang ZY, Zhu GY (2008) Health risks of heavy metals in contaminated soils and food crops irrigated with treated wastewater in Beijing, China, vol 152. Department of Environmental Sciences, University of Peshawar Environmental, Peshawar, pp 686-692

Marschner H (2002) Mineral nutrition of higher plants. Academic Press, Amsterdam, pp 657-680

Naz H, Naz A, Ashraf S (2015) Impact of heavy metal toxicity to plant growth and nodulation in Chickpea grown under heavy metal stress. Int J Res Emerg Sci Technol 2(5):2349-7610

Nriagu JO (1984) Changing metal cycles and human health. Springer, New York

Parveen T, Hussain A, Rao S (2015) Growth and accumulation of heavy metals in turnip (Brassica rapa) irrigated with different concentrations of treated municipal waste water. Hydrol Res 46(1):60-71

Patil SS, Gandhe DH, Ghorade BI (2014) Physicochemical properties of soil samples of Ahmednagar Industrial area. Global Res Anal (GRA) 3(4):2277-8160

Sahito OM, Kazi T, Afridi HI, Kori NG (2016) Assessment of toxic metal uptake by different vegetables grown on soils amended with poultry waste: risk assessment. Water Air Soil Pollut 227(11):423. https://doi.org/10.1007/s11270-016-3123-5

Sutherland RA, Tolosa CA, Trck FMG, Verloo MG (2000) Characterization of selected element concentrations and enrichment ratio in background and anthropogenically impacted roadside areas. Arch Environ Contam Toxicol 38:428-438

Zhang J, Liu CL (2002) Riverine composition and estuarine geochemistry of particulate metals in China weathering features, anthropogenic impact and chemical fluxes. Estuar Coast Shelf Sci 54:1050-1070

Publisher's Note Springer Nature remains neutral with regard to jurisdictional claims in published maps and institutional affiliations. 